\title{
Dorota Pudo
}

Uniwersytet Jagielloński

dorota.pudo@wp.pl

\section{SUBIEKTYWNE TEORIE NA TEM AT UCZENIA SIĘ JĘZYKA OBCEGO STUDENTÓW ROM ANISTYKI}

\section{Subjective theories about learning foreign languages in Romance Philology students}

\begin{abstract}
Research on subjective (implicit) theories, similarly to studies on other kinds of beliefs, has a rich tradition in the SLA field. This study presents the results of a survey conducted among 55 Romance Philology students, containing open-ended questions about different aspects of the language learning process: nature of the language itself, learner's personal attributes facilitating learning, effective learning activities, optimal learning environment, obstacles to learning, role played by other people. Due to the use of a qualitative methodology (open-ended questions), a large variety of different answers was collected. The data were analysed and divided into subject categories, and the answers falling into each category were counted in order to provide an overall view of the group's tendencies. The students' answers mainly confirm that they see learning a language as a long process demanding time and effort. Students' motivation and perseverance prove to be the most important factors whereas features such as intelligence or language aptitude are underestimated.
\end{abstract}

Keywords: subjective theories, foreign language learning

Słowa kluczowe: teorie subiektywne, uczenie się języków obcych

\section{Wprowadzenie}

Subiektywne teorie, zwane także teoriami naiwnymi (w odróżnieniu od naukowych), osobistymi, implicytnymi lub codziennymi (por. Martinez, 2008: 
106), są stosunkowo mało zbadaną różnicą indywidualną w porównaniu z takimi zmiennymi jak osobowość czy inteligencja. Początki badań nad nimi sięgają lat 50., a za ich prekursora można uznać George'a Kelly'ego, który w swojej książce "The psychology of personal constructs" (1955) opisywał to, jak osobiste przekonania przejawiane w codziennym życiu wpływają na percepcję siebie i innych (por. Ryan i M ercer, 2012: 75). Słynne badania Carol Dweck i jej współpracowników (1995), których wyniki mogą mieć istotne znaczenie dla dydaktyki języków obcych, dotyczą osobistych teorii inteligencji. Badaczka wyróżnia dwa główne typy teorii subiektywnych (tzw. mindsets): stałe (entity theories; inteligencja jest cechą wrodzoną i niezmienną) i wzrostowe (incremental theories; inteligencję można rozwijać). Rodzaj mindset może wpływać na wyniki dzieci w nauce szkolnej, a zmieniając go ze stałego na wzrostowy, można przyczynić się do poprawy wyników uczniów (Blackwell i in., 2007).

Ze względu na potencjalny wpływ osobistych teorii uczniów na wyniki ich wysiłków edukacyjnych, a także stosunkowo niewielkie zainteresowanie badaczy tym tematem, postanowiliśmy przeprowadzić badania mające dać nam wgląd w osobiste teorie studentów na temat uczenia się języków obcych. Przedstawiliśmy studentom filologii romańskiej - a więc osobom, które wiążą swoją przyszłość zawodową właśnie z językiem obcym - obszerną ankietę z pytaniami otwartymi, których celem było poznanie ich przekonań na temat uczenia się języków obcych i na tej podstawie zrekonstruowanie ich ukrytych teorii. W dalszych częściach artykułu przyjrzymy się najpierw najistotniejszym badaniom dotyczącym tej problematyki w glottodydaktyce, następnie przedstawimy cele i metodologię naszych badań, by ostatecznie przejść do prezentacji uzyskanych wyników i dyskusji o nich.

\section{Subiektywne teorie w glottodydaktyce}

W glottodydaktyce refleksja nad przekonaniami i teoriami subiektywnymi uczących się oraz nauczycieli była podejmowana wielokrotnie, na gruncie wielu teorii, a użyteczności badania tej trudnej do uchwycenia, bardzo subiektywnej problematyki nigdy nie kwestionowano. Jak pisze Hélène Martinez, „w psychologii i naukach o edukacji dowiedziono, że subiektywne teorie są ważnym narzędziem wyjaśniania i przewidywania ludzkiego zachowania i myślenia" (2008: 106, tłum. nasze). Problematyka ta coraz częściej jest przedmiotem zainteresowania glottodydaktyków, o czym może świadczyć poświęcony jej w całości tom pt. „Beliefs about SLA” (wyd. Kalaja i Barcelos, 2003). Stephen Ryan i Sarah Mercer definiują ukryte teorie następująco: „Teorie subiektywne (implicit theories albo mindsets) odnoszą się do fundamentalnych, podstaw owych przekonań żywionych przez jednostki, dotyczących natury i plastyczności różnych 
aspektów kondycji ludzkiej" (2012: 74, tłum. nasze). Autorzy ci uważają, że badania nad subiektywnymi teoriami jako takimi w glottodydaktyce są stosunkowo nieliczne (78). Należą do nich badania Elaine Horwitz (1988), która stworzyła popularne do dzisiaj narzędzie pomiaru przekonań uczących się na temat różnych aspektów procesu nabywania języka obcego, kwestionariusz BALLI (Beliefs About Language Learning Inventory). Przy pomocy różnych jego wersji autorka oraz jej współpracownicy i naśladowcy przeprowadzili wiele badań, które pozwoliły zidentyfikować najpowszechniejsze przekonania wśród badanych grup i różne relacje między nimi (por. Kuntz, 1996). Kwestionariusz ten zawiera listę stwierdzeń, wyrażających stereotypowe przekonania na temat uczenia się języka obcego, dotyczące np. roli płci czy też wieku w tym procesie, do których badani muszą się ustosunkować na pięciostopniowej skali. Inne badania związane z przekonaniami i osobistymi teoriami w uczeniu się języka przeprowadziła M ori (1999), która wykazała między innymi, że „silna wiara w rolę wrodzonych zdolności jest związana z niższymi osiągnięciami" (408, tłum. nasze), a także Ryan i M ercer, którzy ustalili, że badany przez Dweck wymiar stałości inteligencji jest tylko jednym z czynników, które kształtują teorie subiektywne uczących się języka i mogą mieć wpływ na wyniki tej nauki (2012: 84). Na uwagę zasługuje również badanie M artinez (2008) dotyczące subiektywnych teorii przyszłych nauczycieli języka w kontekście autonomii uczenia się oraz badania zebrane we wspomnianym już tomie pt. „Beliefs about SLA” (wyd. Kalaja i Barcelos, 2003), skupiające się zwłaszcza na kontekstualnych, społecznych i kulturowych uwarunkowaniach przekonań o uczeniu się języków obcych.

$\mathrm{Na}$ gruncie polskim badania z użyciem stwierdzeń częściowo zapożyczonych z kwestionariusza BALL przeprowadziła niedawno Anna Michońska-Stadnik (2013). Badała ona studentów anglistyki przygotowujących się do wykonywania zaw odu nauczycieli pod kątem stopnia akceptacji przez nich wybranych stwierdzeń, uznanych przez badaczkę, na podstawie refleksji teoretycznej omówionej w tej samej książce, za "niebezpieczne stereotypy lub co najmniej za twierdzenia mocno dyskusyjne" (37). Sprawdzała też, czy po pewnej liczbie zajęć na studiach nauczycielskich wiara w stereotypy słabła u studentów, a także, jak przedstawiała się ona u osób odpowiedzialnych za ich kształcenie. Należy wymienić także badania na studentach filologii angielskiej przeprowadzone przez Adrianę Biedroń (2008), która badała, oprócz czynników afektywnych niezwiązanych bezpośrednio z tematem naszego artykułu, dwa główne aspekty przekonań studentów odnośnie do uczenia się języka obcego wyrażone następującymi pytaniami badawczymi: "Jak uczący się języka obcego, postrzegają możliwość kontroli poszczególnych aspektów uczenia się języka obcego?" i "Jak uczący się języka obcego postrzegają relację między atrybucją przyczynową osiągnięcia przez nich lub nie celu w uczeniu się języka i emocjami odczuwanymi 
w wyniku procesu atrybucji?" (104, tłum. nasze). Jednym z najbardziej interesujących z punktu widzenia teorii osobistych wyników tego badania było określanie przez studentów bardzo wielu zmiennych jako podlegających ich kontroli, "nawet w odniesieniu do czynników zwykle uważanych za niekontrolowalne, takich jak zdolności, trudność zadania, okoliczności i czas" (Biedroń, 2008: 114, tłum. nasze). Do problematyki przekonań studentów (różnych kierunków) na temat uczenia się języków obcych nawiązuje też niedawne badanie Macieja Smuka (2016), przeprowadzone za pomocą bardzo interesującej, jakościowej metodologii pisemnej autobiografii. Do uzyskanych przez autora wyników będziemy odwoływać się w dyskusji, zestawiając je z naszymi.

\section{Opis badania: cele, metodologia i uczestnicy}

Celem naszego badania jest zapoznanie się z jak największym zakresem przekonań studentów romanistyki na temat uczenia się języka obcego, leżących u podstaw ich osobistych teorii uczenia się języka obcego. Jest to badanie eksploracyjne, mające pozwolić nam ustalić podstawowe, spontanicznie pojawiające się poglądy studentów na interesującą nas kwestię. Jakie czynniki osobowościowe, materialne, sytuacyjne mają wpływ, zdaniem badanych, na proces nauki języka obcego? Co może go ułatwić, a co utrudnić? Czy odpowiedzi dają obraz raczej „stałej” czy raczej „wzrostowej” teorii subiektywnej tego procesu, tzn. czy zdaniem studentów można poprawić skuteczność swojego uczenia się, czy jest ona czymś danym, względnie niezmiennym i od nich niezależnym?

Przeprowadzone przez nas badanie jest badaniem jakościowym, czyli ujmuje zjawisko w sposób globalny i indukcyjny; opiera się na danych zebranych w sposób otwarty, a kategorie ich analizy wyłaniane są w toku analizy; ponadto, na wszystkich etapach ważny dla badacza jest sposób myślenia osób badanych (Wilczyńska i M ichońska-Stadnik, 2010: 139). Postanowiliśmy policzyć także procent osób udzielających konkretnych odpowiedzi, celem ukazania ogólnych tendencji przeważających w badanej grupie (por. Smuk, 2016: 163-164). Nasza ankieta składa się wyłącznie z pytań otwartych, mających zostawić badanym jak największą swobodę wypowiedzi. Zdajemy sobie sprawę z trudności takiego podejścia, które może okazać się kłopotliwe na poziomie analizy, zostawia respondentom dużą swobodę co do zakresu i długości odpowiedzi (por. Wilczyńska i Michońska-Stadnik, 2010: 172), a także opiera się (podobnie jak wiele ankiet o pytaniach (pół)zamkniętych) na danych introspekcyjnych, których wiarygodność bywa ograniczana przez nieszczerość respondentów czy niedostateczną dostępność poznawczą badanych treści (por. jw. 161), a także zniekształcenia związane z pamięcią (konieczność dokonania retrospekcji). Z drugiej strony, użycie zamkniętych kwestionariuszy w oczywisty 
sposób wpływa na badanych, narzucając im zakres tematyczny odpowiedzi i ograniczając je do aspektów, które pojawiły się w kwestionariuszu, a o których spontanicznie mogliby w ogóle nie pomyśleć (por. Ryan i Mercer, 2012: 80).

Cechą specyficzną badanej problematyki jest fakt, że dotyczy ona subiektywnych przekonań respondentów w dziedzinie dla nich ważnej (obszar działalności wybrany jako pole przyszłej aktywności zawodowej), lecz względnie bezpiecznej dla ego badanych (nie pytamy o ich własne sukcesy i porażki, ale o ich ogólne przekonania dotyczące elementów niezbędnych do tego, żeby taki sukces odnieść), stąd ryzyko zniekształceń poznawczych lub nieszczerości wydaje nam się stosunkowo niewielkie. Pewnym zagrożeniem może być relatywna trudność ankiety: badani, którzy nie zastanawiali się wcześniej nad problemami, o które w niej pytamy, mogą mieć trudności skutkujące udzieleniem odpowiedzi niedbałych lub nieprzemyślanych. Nie chcą c ryzykować zniekształcenia przekonań osób badanych przez sugerowanie im konkretnych opcji, zdecydowaliśmy się na ogólne pytania, takie jak: „Jaką trzeba być osobą, żeby odnieść sukces w nauce języka obcego?", zakładając, że jeśli badany uważa jakiś czynnik (np. płeć, wiek czy talent) za istotny, jego dostępność poznawcza będzie duża i spontanicznie o nim wspomni. Celem uzyskania większej liczby odpowiedzi i bardziej pogłębionej refleksji zadaliśmy kilka podobnych pytań, których przedmiotem są różne aspekty procesu uczenia się języka (cechy uczącego się, czynności, które powinien podjąć, przedmioty, którymi powinien dysponować, okoliczności, które powinny temu procesowi towarzyszyć itp.). Razem ze wstępnym pytaniem o definicję samego języka, pytań dotyczących subiektywnych teorii uczenia się języka obcego było siedem ${ }^{1}$. Takie rozbicie problemu badawczego na kilka pytań spełniło, naszym zdaniem, swoją rolę, prowadząc do uzyskania szerszego spektrum odpowiedzi, uwzględniającego także aspekty mniej oczywiste. Jego wadą natomiast była pewna powtarzalność (te same wątki pojawiają się w odpowiedziach na poszczególne pytania) oraz to, że być może niektóre odpowiedzi generowane były przez badanych wyłącznie w celu uniknięcia powtórzenia podanej już wcześniej odpowiedzi. Niektóre osoby pomijały odpowiedzi na kolejne pytania, być może zakładając, że napisały już wszystko, odpowiadając na pytania wcześniejsze.

Ankiety wypełniła grupa 55 studentów filologii romańskiej UJ w czerwcu 2016. Wypełnienie ankiety było anonimowe i dobrowolne: poproszeni przez nas

\footnotetext{
${ }^{1}$ Ankieta zawierała ponadto dwa pytania dotyczące idealnego nauczyciela języka obcego (jego cech i sposobów postępowania) oraz część dotyczącą biografii językowej studenta, tzn. jego doświadczeń językow ych i skojarzeń z poszczególnymi językami, lecz te części nie podlegają analizie na użytek niniejszego artykułu. Wyniki uzyskane w części dotyczącej biografii językowej analizujemy w osobnym artykule (Pudo, 2016).
} 
o pomoc w organizacji badania prowadzący zajęcia rozprowadzali je w trakcie zajęć lub wysyłali mailem studentom, zachęcając do zwrotu wypełnionych ankiet; niektórzy zorganizowali wypełnianie ankiet na zajęciach. Pytania ankiety poprzedzone były krótką instrukcją; dla części podlegającej analizie w niniejszym artykule brzmiała ona następująco: „Proszę pomyśleć, jak według Pana/i skutecznie nauczyć się języka obcego. Proszę napisać wszystko, co przyjdzie Panu/i do głowy. Proszę spróbować uwzględnić następujące aspekty". Studenci, wśród których rozprowadzaliśmy ankietę osobiście, a także prowadzący rozdający ją innym grupom, otrzymali informację o celu badania (poznanie poglądów studentów na skuteczną naukę języków obcych). Udało nam się uzyskać, choć w nierównych proporcjach, odpowiedzi studentów wszystkich lat poza trzecim rokiem studiów licencjackich (11 odpowiedzi studentów I roku studiów licencjackich, 6 odpowiedzi studentów II roku, 17 odpowiedzi studentów I roku studiów magisterskich i 21 odpowiedzi studentów II roku studiów magisterskich).

Analiza ankiet polegała na redukcji danych poprzez kodowanie określonych fragmentów odpowiedzi, istotnych z punktu widzenia postawionych pytań badawczych (por. Rubacha, 2008: 261-264). Każda odpowiedź pozwoliła nam wyróżnić kilka dominujących kategorii tematycznych, którym przypisaliśmy odpowiednie etykiety. Kategorie te obejmowały w sposób wyczerpujący wszystkie otrzymane przez nas odpowiedzi; odpowiedzi udzielane rzadko, a niepasujące do żadnej z kategorii, grupowaliśmy w kategorii „inne”. W instrukcji nie ograniczaliśmy liczby odpowiedzi, zatem wielu respondentów udzielało ich po kilka, stąd procenty poszczególnych odpowiedzi nie sumują się do 100. Jeśli jeden respondent udzielił kilku odpowiedzi mieszczących się w jednej kategorii, liczyliśmy je jako jedną odpowiedź, chcąc uniknąć sztucznego powiększania się niektórych kategorii dzięki osobom, które bardziej wylewnie wyrażają swoje myśli, używają synonimów bądź chcąc dokładnie wyłożyć, o co im chodzi, rozwijają podobną ideę kilkukrotnie. Dlatego procent odpowiedzi w danej kategorii należy rozumieć jako procent osób, które jej udzieliły. Kiedy analizujemy konkretne odpowiedzi wewnątrz danej kategorii (w przypadku tych kategorii, które gromadzą bardziej zróżnicowane odpowiedzi), liczba poszczególnych odpowiedzi rośnie, gdyż jedna osoba mogła udzielić kilku należących do danej kategorii.

Początkowo, analizując odpowiedzi na poszczególne pytania, analizowaliśmy je osobno dla studentów każdego roku oraz osobno dla studentów studiów licencjackich (17 osób) i magisterskich (38). Spodziewaliśmy się, że różnica w doświadczeniu w uczeniu się języków obcych, a także uzyskiwana w toku studiów wiedza dydaktyczna mogą mieć wpływ na przemyślenia badanych. Nie udało nam się jednak znaleźć żadnych istotnych statystycznie różnic w odpowiedziach między tymi grupami, stąd w kolejnych sekcjach przedstawiamy jedynie łączny wynik ankiety. Odpowiedzialna za taki stan rzeczy może 
być, oprócz ewentualnego rzeczywistego braku rozbieżności, zbyt mała liczba badanych i zbytnia dysproporcja w liczbie uczestników poszczególnych grup.

\section{Wyniki}

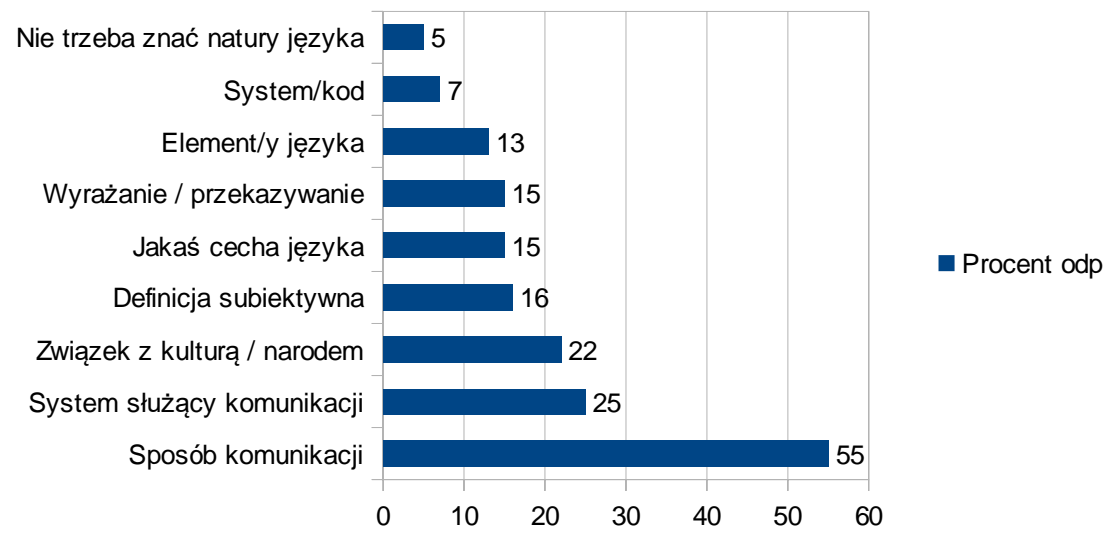

Ilustracja 1: Odpowiedzi na pytanie 1: Czym jest język?

Pierwsze pytanie - czym jest język? - było wstępem do kolejnych i jego zadanie uwarunkowane było założeniem, że obraz samego języka może mieć istotny wpływ na przekonania o sposobie jego przyswajania. Zdecydowana większość osób (80\%) widzi w nim narzędzie komunikacji; niektórzy zauważają przy tym, że jest on pewnym systemem czy też kodem, że posiada pewne reguły. Przewaga pojęcia komunikacji w odpowiedziach studentów wskazuje na pragmatyczne i funkcjonalne ujęcie przez nich języka. Dla 22\% badanych ważny jest także związek języka z narodem, który go używa, jego mentalnością czy też specyfiką, bądź jego kulturą czy konkretnym przejawem, takim jak piśmiennictwo czy literatura. 16\% udziela odpowiedzi o strukturze definicji, lecz wskazuje taki aspekt języka, który nie jest powszechnie uważany za jego cechę definicyjną (choć mogą być to ważne cechy), stąd określiliśmy te odpowiedzi jako definicje subiektywne. Przykładowe odpowiedzi z tej kategorii to: język jako sposób widzenia świata, sposób odkrywania siebie i innych, narzędzie rozwoju. 15\% wskazuje na ekspresyjne lub informacyjne funkcje języka, a dalsze $15 \%$ podaje w ramach definicji jakąś cechę języka, np. jeden respondent pisze, że uczy on logicznego myślenia, inny, że jest ogromem nie do poznania, kolejny, że jest przeźroczysty jak powietrze, inni zwracają uwagę na jego umowność czy wielowymiarowość. 13\% kładzie nacisk na jeden lub kilka elementów lub podsystemów języka. Zaledwie 4 osoby definiują język jako system lub kod, a 3 dalsze zauważają 
w ramach, a może zamiast odpowiedzi, że to pytanie zainteresuje tylko filologa i że nie trzeba znać natury języka, żeby się go uczyć.

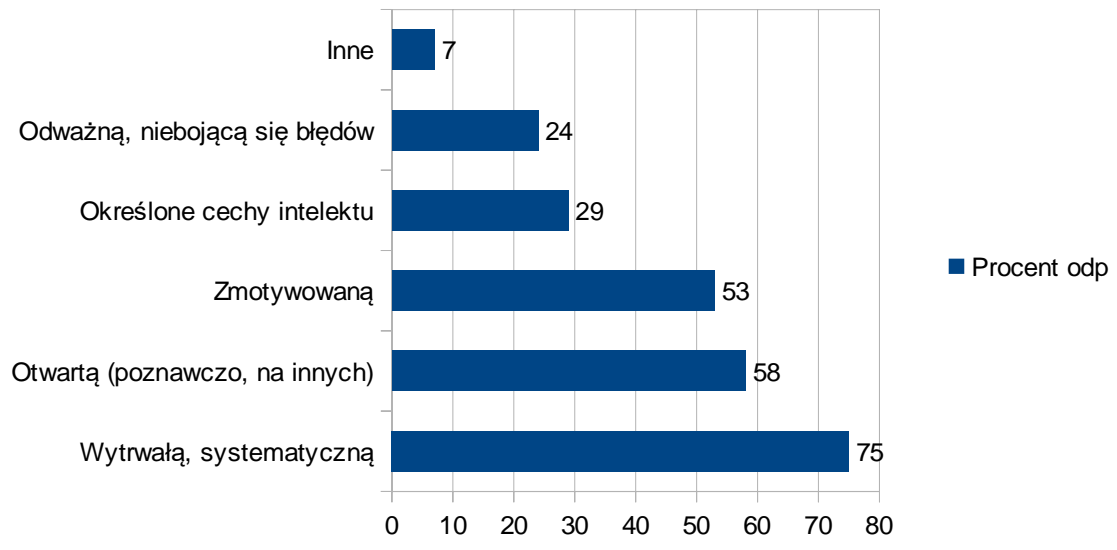

Ilustracja 2: Odpowiedzi na pytanie 2: Jaką osobą trzeba być, żeby odnieść sukces w uczeniu się języka obcego?

Jeśli chodzi o cechy osoby, która odnosi sukces w nauce języków obcych, przeważająca większość respondentów wskazała na wytrwałość, systematyczność, samodyscyplinę, konsekwencję i inne cechy wskazujące na to, że uczenie się języka obcego uważają za długi, żmudny proces, wymagający cierpliwości i wysiłku. Drugą ważną cechą wskazaną przez ankietowanych jest otwartość, ciekawość świata, gotowość do spotykania się z innymi ludźmi i kulturami, co z kolei wskazuje na to, że dla badanych uczenie się języka jest procesem wymagającym nie tylko zaangażowania, ale też pewnego określonego nastawienia. Kolejna kategoria odpowiedzi dotyczy motywacji: badani mówią o chęci do nauki, zainteresowaniu danym językiem lub kulturą czy miłości do nich, o determinacji. Prawie 30\% respondentów wymienia też jakąś cechę intelektu, którą powinien - lub nie musi - dysponować uczący się języka obcego, żeby odnieść sukces. Większość badanych wymienia talent, lecz jest to tylko 7 osób z 55, dodatkowo dwie osoby piszą, że ich zdaniem rola tzw. talentu językowego jest przeceniana. Pozostałe cechy intelektu są wymienione przez dwie osoby: wyobraźnia, kreatywność, logiczne myślenie lub przez jedną: dobra pamięć, inteligencja, uważność, dobre kojarzenie. Kolejny czynnik, na który wskazała prawie jedna czwarta badanych, to odważne, pozytywne podejście do błędów: zdaniem respondentów, nie należy się ich lękać, trzeba za to wyciągać z nich wnioski, nie wolno także bać się mówić czy kontaktować się z innymi, w tym rodowitymi użytkownikami nabywanego języka. Warto także odnotować, że 
zdaniem dwóch osób każdy może nauczyć się języka obcego (odpowiedź przypisana do kategorii „inne”).

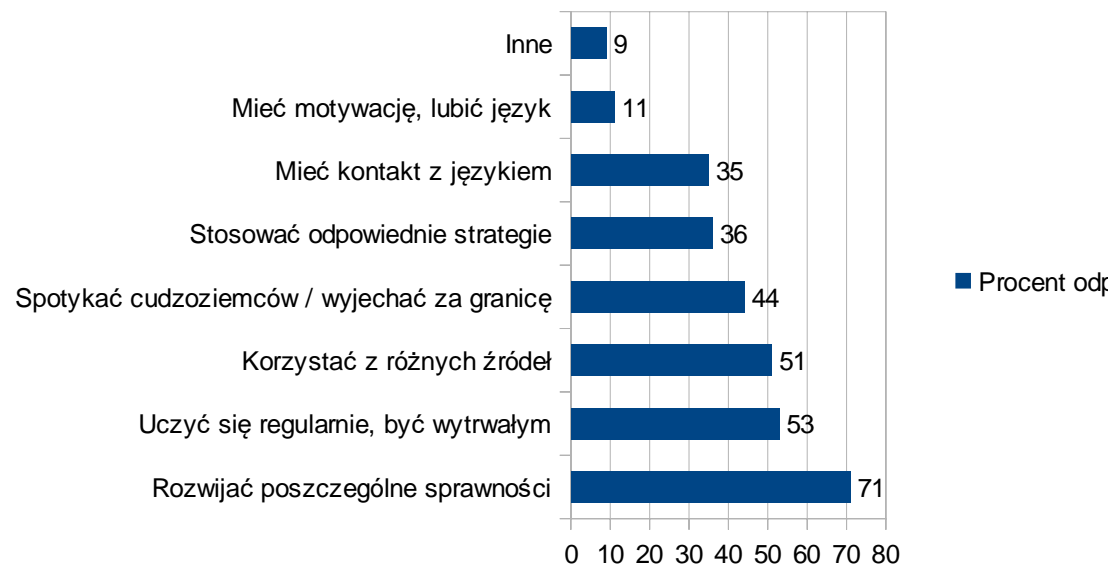

Ilustracja 3: Odpowiedzi na pytanie 3: Co trzeba robić, żeby nauczyć się języka obcego?

Analizując odpowiedzi udzielone przez badanych na pytanie o czynności, które należy podjąć, żeby nauczyć się języka obcego, widać, że pewne odpowiedzi się powtarzają: badani znów zauważają, że trzeba być wytrwałym, uczyć się regularnie (53\%) i posiadać dużą motywację, lubić język (11\%). Mamy jednak także odpowiedzi bardziej specyficzne. Najwięcej osób wskazało na konieczność rozwijania poszczególnych sprawności językowych, wymieniając kilka lub jedną z nich. Co zaskakujące, najwięcej osób zaleciło czytanie (24), mniej słuchanie (15), kolejno mówienie (14), uczenie się słownictwa (9), gramatyki (6), pisanie (2) i jedna osoba zauważyła, że należy równolegle rozwijać wszystkie sprawności. Ponad połowa badanych wskazała na konieczność sięgania do różnych źródeł, czasami podała, o jakie konkretnie źródła chodzi: filmy (21), telewizja (8), radio (8), muzyka (6), Internet (3), różne źródła (3), technologia (1) i książki (1). Zaskakiwać może przewaga mediów tradycyjnych nad nowymi mediami interaktywnymi - tylko trzy osoby wspominają o Internecie lub aplikacjach z nim związanych - jednak naszym zdaniem nie świadczy to o rzeczywiście rzadszym korzystaniu z tego medium, zwłaszcza że telewizja, radio, filmy i muzyka mogą być znalezione na stronach internetowych. W kolejnych pytaniach kwestia Internetu powróci, zauważona przez większą liczbę osób.

Prawie połowa badanych doradziłaby uczącym się języka spotkanie z obcokrajowcami lub wyjazd za granicę, przy czym ta pierwsza sugestia była ponad dwukrotnie częstsza. Taka sama liczba osób wskazała w swoich odpowiedziach 
pewne strategie, niezwiązane bezpośrednio z poszczególnymi sprawnościami językowymi. Tutaj odpowiedzi były bardzo zróżnicowane. Najwięcej osób wskazało na konieczność wykonywania ćwiczeń (9 osób), pozostałe odpowiedzi zostały udzielone przez 1 lub 2 osoby, niektóre z nich się wzajemnie wykluczają. Oto kilka przykładów: mieć plan, stawiać sobie cele, myśleć w języku obcym, stosować tradycyjne metody, uczyć się na pamięć, „nie wkuwać słówek na pamięć”.

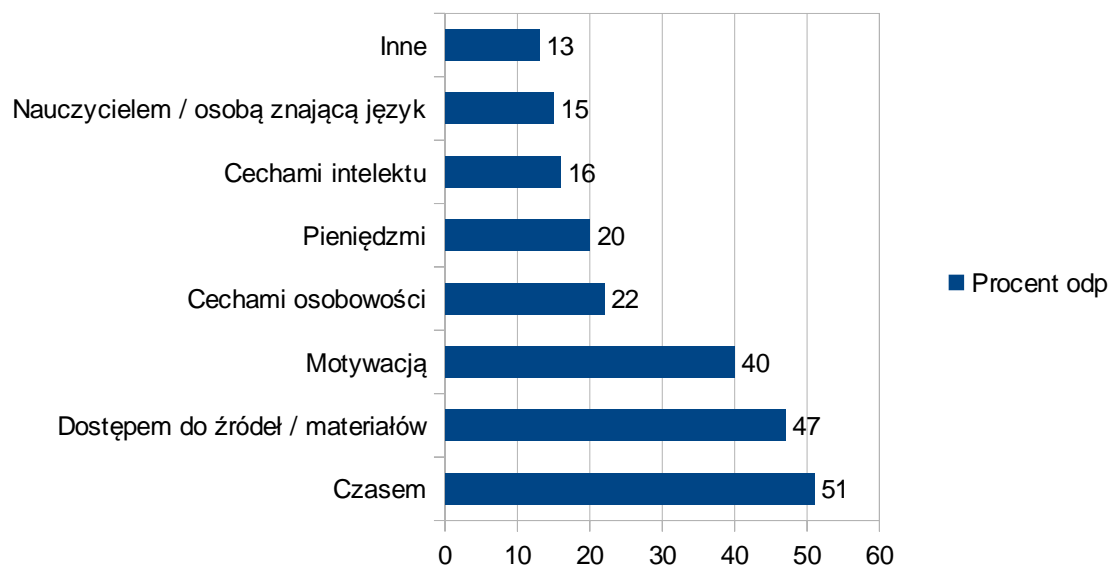

Ilustracja 4: Odpowiedzi na pytanie 4: Czym trzeba dysponować, żeby nauczyć się języka obcego?

Odpowiedzi na pytanie o to, czym trzeba dysponować, żeby nauczyć się języka obcego, dobrze uzupełniają się z odpowiedziami na poprzednie pytania. Skoro zdaniem badanych osoba ucząca się języka obcego musi przede wszystkim być wytrwała i cierpliwa, nie należy się dziwić, że wśród dóbr, którymi musi dysponować, na pierwszym miejscu znalazł się czas: wskazało go aż 28 osób. Potwierdza to obraz nauki języka jako żmudnego, długotrwałego procesu, który nie ma nic wspólnego z przekazem płynącym z reklam. Dalsze w kolejności są źródła i materiały, które pojawiły się już w odpowiedziach na poprzednie pytanie, teraz jednak studenci wymienili nieco inne źródła, kładąc większy nacisk na Internet (15), ale także na tradycyjne materiały papierowe: podręczniki (9), słowniki (9), książki (8). Ponadto 10 osób wspomniało ogólnie o źródłach, a 3 - o mediach.

Wśród dalszych odpowiedzi na pytanie 4 wyróżniliśmy dwa zestawy cech, którymi powinien wykazać się uczący się języka obcego: cechy osobowości (otwartość, cierpliwość, rozsądek itp.) oraz cechy intelektu, podobne jak w odpowiedziach na pytanie 2, choć mniej liczne (np. talent - 6 osób, inteligencja 1 osoba, dobra pamięć - 2 osoby). W kategorii „różne” znalazła się inna wymagana 
cecha osobista, a mianowicie dobry słuch, zdolności muzyczne. 20\% badanych wskazało na użyteczność dysponowania pieniędzmi (niektórzy precyzowali, że chodzi o środki na wyjazd, kurs czy materiały), przy czym dwie zaznaczyły, że wielkie nakłady finansowe nie są wcale niezbędne do opanowania języka obcego. Ostatnią wyróżnioną przez nas w tym pytaniu kategorią był nauczyciel (ewentualnie inna osoba dobrze znająca język obcy), o którym wspomniało $15 \%$ badanych, zaznaczając, że powinien być to dobry nauczyciel.

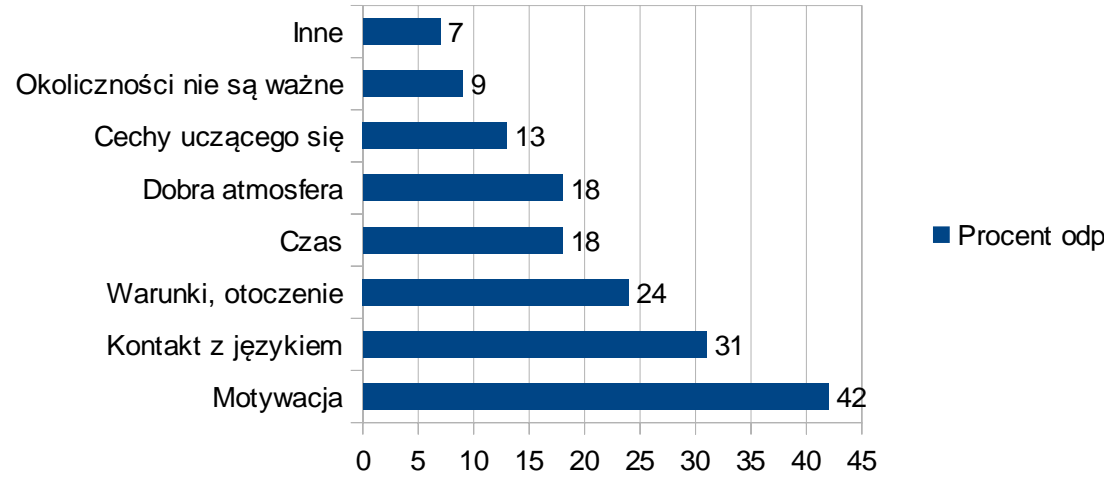

Ilustracja 5: Odpowiedzi na pytanie 5: Jakie okoliczności muszą towarzyszyć nauce języka obcego?

W przypadku odpowiedzi na pytanie o okoliczności, które powinny towarzyszyć skutecznej nauce języka, widać, że pomysłowość studentów stopniowo się wyczerpuje, a odpowiedzi są coraz mniej specyficzne dla danego pytania. Powtarzają się kwestie podnoszone już poprzednio - związane z motywacją (chęć do nauki, pozytywny stosunek do języka itp.), koniecznością kontaktu z językiem (przy czym 8 osób zaleciło pobyt w kraju docelowym, a 7 kontakt z rodzimym lub biegłym użytkownikiem języka), czasem czy pewnymi cechami uczących się, takimi jak cierpliwość, otwarty umysł, energiczność. Co ciekawe, tylko jedna osoba wymieniła wśród tych cech młody wiek, choć przekonanie o wyższości dzieci nad dorosłymi w opanowywaniu języka obcego jest często przywoływane jako rozpowszechniony stereotyp (por. M ichońska-Stadnik, 2013: 39). Pojawiło się także kilka odpowiedzi, z którymi nie mieliśmy do czynienia przy w cześniejszych pytaniach. Pierwsza z takich kategorii to odpowiedzi odnoszące się do warunków nauki, okoliczności zewnętrznych, czyli kwestii poruszonej wprost w pytaniu. Niestety było ich stosunkowo niewiele, i jedyne odpowiedzi z tej kategorii, które podała więcej niż jedna osoba, to spokojne miejsce (6 osób), ogólne środowisko umożliwiające naukę (2 osoby) oraz wsparcie 
kogoś bliskiego (2 osoby). M ożemy z tego wywnioskować, iż zewnętrzne okoliczności nie mają dla badanych tak wielkiej wagi, jak pewne cechy wewnętrzne, zwłaszcza motywacja i nastawienie. Potwierdzają to wypowiedzi zebrane przez nas w osobnej kategorii, wyrażające taką opinię wprost, niejako zamiast odpowiedzi na pytanie ankiety (9\%). Osobno też skategoryzowaliśmy odpowiedzi dotyczące pożą danej atmosfery, która bywała przez badanych określana jako dobra, luźna czy bezstresowa. Jest to jedno z nielicznych miejsc w ankiecie, w którym respondenci wspomnieli o szkodliwości lęku językowego dla nauki języka, choć jest to jedna ze zmiennych psychologicznych o najlepiej udowodnionym negatywnym wpływie na proces przyswajania języka obcego (Arnold i Brown, 1999: 8).

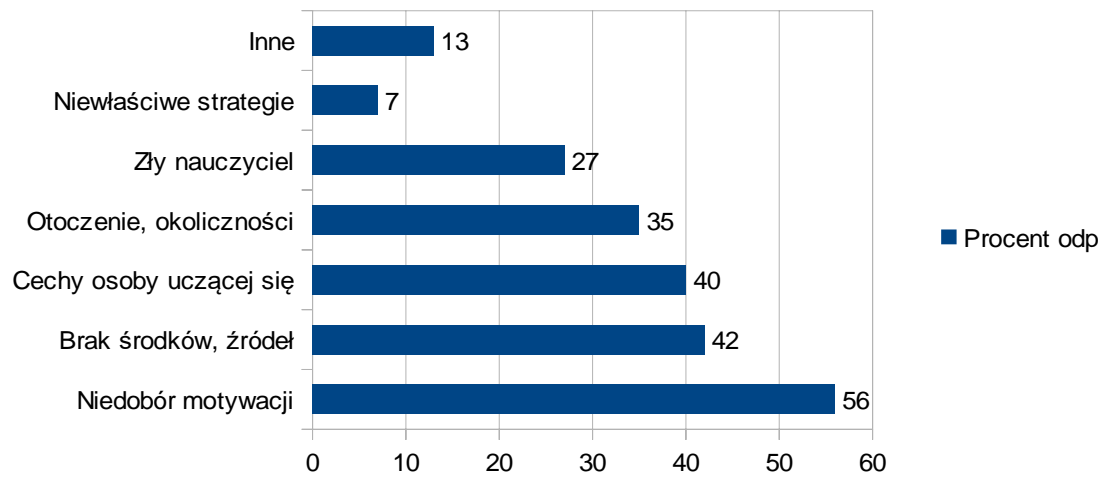

Ilustracja 6: Odpowiedzi na pytanie 6: Co może utrudnić lub uniemożliwić naukę języka obcego?

Kolejne pytanie sformułowaliśmy w nieco inny sposób, prosząc o wskazanie tego, co może utrudnić lub uniemożliwić proces przyswajania języka obcego. Najważniejszym czynnikiem zagrażającym nauce, wskazanym przez ponad połowę badanych, okazują się, symetrycznie do poprzednich pytań, niedobory motywacji, przejawiające się zniechęceniem (zwłaszcza na początku), brakiem odporności na niepowodzenia, zwątpieniem w siebie lub w powodzenie, „słomianym zapałem". Kolejna odpowiedź nawiązuje również do pojawiających się wcześniej wątków, wskazujących na konieczność regularnego kontaktu z językiem i dostępu do różnorodnych źródeł. Wydaje się zatem logiczne, że w ich braku badani upatrują czynnika potencjalnie utrudniającego proces przyswajania.

W kolejnej odpowiedzi badani wskazują na pewne cechy, które mogą okazać się kłopotliwe dla uczącego się języka obcego. Najczęściej wymieniana z nich - brak systematyczności czy wytrwałości (10) - odpowiada czynnikom wymienianym wcześniej najliczniej jako konieczne dla skutecznej nauki, podobnie jak lenistwo (3), 
nieśmiałość (2), lęk przed błędami (3). 4 osoby wskazują na brak talentu, co również jest logiczne w świetle faktu, że wcześniej podobnie niewielu badanych wskazywało na talent jako cechę konieczną. Podobnie jak w poprzednim pytaniu, tylko jedna osoba wskazuje zaawansowany wiek jako potencjalną przeszkodę.

Jeśli chodzi o zewnętrzne okoliczności, za najbardziej szkodliwy uznany został zewnętrzny przymus i presja (8 osób), co również jest zrozumiałe w świetle ogromnej wagi, jaką badani przywiązują do motywacji, chęci, zainteresowania językiem itp. Inne odpowiedzi to np. niewłaściwie rozłożony w czasie materiał, zbyt duża grupa czy problemy osobiste. Zaledwie 7\% osób wskazało na niewłaściwe strategie jako potencjalną przyczynę porażki (brak celów, zła metoda, uczenie się słówek na pamięć, uczenie się naraz kilku podobnych języków). Jednak rzeczą, która najbardziej nas uderzyła w odpowiedzi na to pytanie, jest stosunkowo duża liczba osób (27\% badanych), które wskazały na złego nauczyciela jako potencjalną przyczynę niepowodzenia. Wcześniej tylko 15\% osób wskazało na dobrego nauczyciela - lub innego doświadczonego użytkownika przyswajanego języka - jako zasób, którym uczący się powinien dysponować. Ta dysproporcja może wskazywać na większą trwałość czy dostępność poznawczą negatywnych doświadczeń z własnymi nauczycielami. M oże też świadczyć 0 asymetrii atrybucyjnej korzystnej dla ego, która każe sobie (swoim cechom, wysiłkowi itp.) przypisywać sukcesy w uczeniu się języka, zaś innej osobie porażki. Interesujące wydają nam się też niektóre odpowiedzi, których nie udało nam się przypisać do żadnej kategorii, np. 3 osoby wskazały na barierę / blokadę językową jako potencjalne źródła problemów. Jedna osoba wyraziła opinię, że właściwie wszystko może utrudnić proces uczenia się języka, a jedna, wręcz przeciwnie, napisała, że nie ma takiej rzeczy.

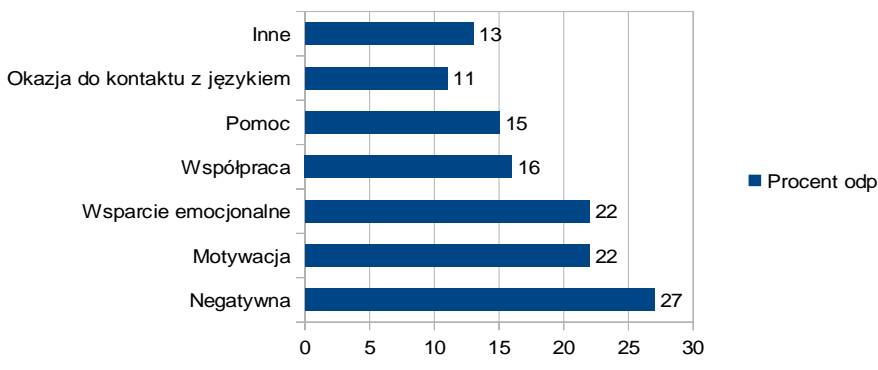

Ilustracja 7: Odpowiedzi na pytanie 7: Jaka jest rola innych osób w nauce języka obcego?

Ostatnie zadane przez nas pytanie dotyczyło roli innych osób w nauce języka obcego. Ponad jedna czwarta badanych wskazała, bezpośrednio lub pośrednio, możliwe negatywne działania innych osób, wśród których znalazły 
się: zniechęcanie (10 osób), przymuszanie (3), wyśmiewanie (3), przeszkadzanie (2). Udzielenie tego typu odpowiedzi przez tak dużą liczbę osób może wskazywać na negatywne doświadczenia studentów z własną rodziną lub współtowarzyszami nauki. Zdecydowanie przeważają jednak odpowiedzi wskazujące na pozytywną rolę innych osób w procesie nauki języka obcego. Dostarczają one motywacji (przez zachęcanie i chwalenie, ale też porównania i rywalizację), wsparcia psychologicznego, ale też konkretnej pomocy (np. rodzice finansują naukę), pozwalają na wspólną naukę, dzielenie pasji, a wreszcie dostarczają okazji do kontaktu z językiem, którego istotność była w tej ankiecie wielokrotnie przez badanych uwypuklana. Pojawiły się odpowiedzi przypisujące innym osobom niesprecyzowaną, lecz dużą rolę w nauce języka (2), ale były też takie, z których wynika, że jest ona nieistotna (2).

\section{Dyskusja}

Wyniki naszych badań wskazują, że w uczeniu się języka obcego, rozumianego przede wszystkim jako narzędzie komunikacji, dla studentów najbardziej liczą się wytrwałość, systematyczność i inne cechy wskazujące na to, że uczenie się języka obcego uważają oni za długi, żmudny proces, wymagający cierpliwości i wysiłku, mimo obecnego w mediach i reklamach niektórych szkół czy metod przekazu obiecującego szybkie i łatwe opanowanie języka obcego. Istotna jest dla nich również intelektualna i emocjonalna postawa otwartości: na innych ludzi i kultury, ale także na własne błędy, które uznawane są za nieuchronny etap w procesie przyswajania języka. Nieco inne wyniki uzyskał w swoim badaniu Maciej Smuk (2016: 163-166): to otwartość została wymieniona jako niezbędna przez największą liczbę uczestników, zaś sumienność lub jej wskaźniki (systematyczność, wytrwałość) pojawiały się wyraźnie rzadziej i część respondentów uznała ich rolę za kontrowersyjną (nadmierna sumienność może przerodzić się w nadgorliw ość lub perfekcjonizm, szkodliwy dla nauki języków: 166). Zarówno w naszym badaniu, jak i w badaniu Smuka studenci przywiązują także ogromną wagę do motywacji, konceptualizowanej głównie jako pozytywny stosunek do nauki, zainteresowanie danym językiem. Choć ta zmienna jest przez glottodydaktyków opisywana i analizowana na różne sposoby, jej znaczenie dla sukcesu dydaktycznego jest niekwestionowane (por. np. Dörnyei, 2005: 65-119), więc ten punkt subiektywnych teorii studentów można uznać za zbieżny z opracowaniami naukowymi.

Należy także zauważyć, że nasi badani nie przykładają dużej wagi do (uznawanych zwykle za stosunkowo niezmienne i niezależne od woli) cech intelektu, takich jak inteligencja, pamięć czy talent językowy. Odwrotne wyniki uzyskała Michońska-Stadnik: „Zaskakujące jest to, że całkiem duży odsetek 
młodych ludzi wierzy, że osoby znające języki obce są bardzo inteligentne" (2013: 40). W badaniu Smuka natomiast predyspozycje poznawcze, predyspozycje do nauki języków obcych i inteligencja pojawiają się stosunkowo często, choć nie są to dominujące odpowiedzi (odpowiednio 22,8\%, 17,1\% i 10\%). Odpowiedzi naszej grupy wyróżniają się zatem na tle innych studentów neofilologii (badanie M ichońskiej-Stadnik) czy różnych kierunków (badanie Smuka). To niedocenianie predyspozycji poznawczych łączy się z niemal całkowitym pominięciem innych czynników wrodzonych, takich jak wiek i płeć, choć w innych grupach popularne jest przekonanie, że dzieci uczą się języków lepiej niż dorośli (M ichońska-Stadnik, 2013: 39), a przekonanie o wyższości kobiet nad mężczyznami w tej dziedzinie jest wręcz częścią „, wiedzy powszechnej”, nierzadko potwierdzonej wynikami badań (van der Slik, van Hout i Schepens, 2015). Taka różnica może być wynikiem zastosowanej metodologii (pytania otwarte zamiast gotowych stwierdzeń, z którymi należy się zgodzić lub nie).

Podkreślanie roli czynników dynamicznych i przynajmniej częściowo zależnych od woli, takich jak wytrwałość, sumienność, otwarta postawa, motywacja, poświęcany czas, kontakt z językiem itp. kosztem bardziej stałych czynników poznawczych czy niezmiennych cech demograficznych wydaje nam się dominującą cechą ukrytych teorii studentów na temat badanego zjawiska. Sukces w uczeniu się języka jest dla nich przede wszystkim rezultatem ciężkiej pracy, podejmowanej pod wpływem silnej, głównie wewnętrznej motywacji, o którą wciąż trzeba dbać, aby nie okazała się „słomianym zapałem”. Towarzyszą jej określone postawy (otwartość) i działania (szukanie kontaktu z językiem). Na tej podstawie możemy powiedzieć, że modelowany przez respondentów uczący się jest jednostką stosunkowo autonomiczną, odpowiedzialną za własne uczenie się, a ich teorie osobiste bardziej przypominają "wzrostowe” niż "stałe” mindsets z prac Carol Dweck. Warto zwrócić uwagę, że mówimy o przekonaniach osób, które są już bardzo doświadczone w uczeniu się języków i nierzadko znają dobrze kilka z nich. Z pewnością są świadome ogromu pracy, jaki musiały włożyć w swoje sukcesy, a także faktu, że talent nie wystarczy, choć być może nie doceniają jego znaczenia.

Jednym z najbardziej zaskakujących wyników badania wydaje nam się brak w odpowiedziach respondentów pewnych kategorii, których istotność dla nauki języka jest dobrze udow odniona badaniami. Oprócz wspomnianych wcześniej czynników poznawczych oraz wieku i płci, takim wielkim nieobecnym jest lęk językowy, o którym przy okazji pytania o przeszkody w uczeniu się języka wspomniało zaledwie 6 osób ( 3 o lęku przed popełnieniem błędu i 3 o barierze/blokadzie językowej; dla porównania, w badaniach Smuka wspomniała o nim ponad jedna piąta uczestników - Smuk, 2016: 169), a 18\% uwzględniło go wyłącznie pośrednio, mówiąc o ważności „bezstresowej” atmosfery w nauce języka. Niedocenienie tego czynnika może wiązać się z faktem, że respondenci, 
będący studentami filologii obcej, są bardziej uodpornieni na klasyczny lęk językowy niż inne grupy uczących się, gdyż częściej wystawieni są na sytuacje potencjalnie lękotwórcze, takie jak wypowiedzi (zwłaszcza publiczne) w języku obcym, interakcje z cudzoziemcami, testy językowe itp.

\section{Wnioski}

Wydaje nam się, że ankieta przeprowadzona w grupie 55 studentów romanistyki dała dosyć spójny obraz tego, jak studenci wyobrażają sobie proces uczenia się języka obcego, które czynniki osobowe, rodzaje aktywności czy okoliczności wydają im się istotnie warunkować proces nauki, a które, przeciwnie, utrudniać go lub nie mieć dlań znaczenia. Przede wszystkim należy podkreślić, że jednym z najważniejszych czynników jest motywacja, chęć do pracy, a także wytrwałość, którą można rozumieć jako zdolność utrzymania tej motywacji. Uczenie się języka obcego, rozumianego przede wszystkim w jego aspekcie funkcjonalnym, jako narzędzie komunikacji, jawi się jako długotrwały, czasochłonny, niekiedy zniechęcający proces, który wymaga wykazania się systematycznością, determinacją, odpornością na błędy i niepowodzenia, a któremu nie sprzyjają lenistwo, niecierpliwość czy „słomiany zapał”. Taka subiektywna teoria, wyrażona pośrednio przez badanych, jest bardziej "wzrostowa" niż "stała” i jako taka dobrze rokuje ich ewentualnej przyszłej działalności dydaktycznej: nauczyciel przypisujący sukcesy raczej ciężkiej pracy niż talentowi ma większe szanse skutecznie zmotywować ucznia.

Należy jednak zaznaczyć, że niniejsze badanie ma charakter fragmentaryczny i niepełny. Po pierwsze, stosunkowo niewielka liczba badanych, tylko z jednej uczelni, nie pozwala na uogólnienie wyników: być może inne grupy młodych romanistów mają zupełnie inne opinie. Po drugie, w badaniu zastosowano tylko jedną metodę (pisemny kwestionariusz z pytaniami otwartymi), podczas gdy niektórzy specjaliści zalecają triangulację, tj. łączenie bardziej i mniej ustrukturalizowanych metod (por. Barcelos, 2003: 19-20). Wreszcie, badanie nie ujmuje w żaden sposób społeczno-kulturowego charakteru ukrytych teorii ani ich dynamiki, traktując je jako względnie stałe konstrukty mentalne, choć glottodydaktycy coraz częściej interesują się tymi aspektami w swoich pracach (Barcelos, 2003: 19-27).

\section{BIBUOGRAFIA}

Arnold, J., Brown, H. D. 1999. „A map of the terrain”. (w) Affect in language Learning. (red. J. Arnold). Cambridge: Cambridge University Press, str. 1-24. 
Barcelos, A. M. F. 2003. "Researching Beliefs About SLA: A Critical Review”. (w) Beliefs about SLA. (red. P. Kalaja i A. M. F. Barcelos). Dordrecht: Springer, str. 7-33.

Biedroń, A. 2008. Attribution related affects in second language acquisition. Słupsk: Akademia Pomorska.

Blackwell, L. S., Trzesniewski, K. H., Dweck, C. S. 2007. „Implicit theories of intelligence predict achievement across an adolescent transition: A longitudinal study and an intervention". Child Development, 78(1): 246-263.

Dörnyei, Z. 2005. The Psychology of the Language Learner. Individual Differences in Secod Language Acquisition. New Yersey - Londyn: Laurence Erlbaum Associates, Publishers Mahwah.

Dweck, C. S., Chiu, Ch., Hong, Y. 1995. „Implicit Theories and Their Role in Judgments and Reactions. A World From two Perspectives". Psychological Inquiry, 6, 4: 267-285.

Horwitz, E. K. 1988. „The beliefs about language learning of beginning university foreign language students". Modern Language Journal, 72(3): 283-294.

Kalaja, P. i A. M. Ferreira Barcelos. (red.). 2003. Beliefs About SLA. New Research Approaches. Dordrecht: Kluwer.

Kelly, G. A. 1955. The psyhology of personal constructs. New York: Norton.

Kuntz, P. S. 1996. Beliefs about language learning: the Horwitz model, University of Wisconsin-M adison, http://files.eric.ed.gov/ fulltext/ED397649.pdf, DW 08.12.2016.

Martinez, H. 2008. „The subjective theories of student teachers: Implications for teacher education and research on autonomy". (w) Learner and Teacher autonomy. (red. T. Lamb i H. Reinders). Amsterdam: Benjamins, str. 103-124.

M ichońska-Stadnik, A. 2013. Teoretyczne i praktyczne podstawy weryfikacji wybranych teorii subiektywnych w kształceniu nauczycieli języków obcych. Wrocław: Wydawnictwo Uniwersytetu Wrocławskiego.

M ori, Y. 1999. „Epistemological beliefs and language learning beliefs: What do language learners believe about their learning?" Language Learning, 49 (9): 377-415.

Pudo, D. 2016. „Représentations du français et d'autres langues étrangères chez les étudiants de philologie romane". Romanica Cracoviensia, 16 (4): 249-263.

Rubacha, K. 2008. M etodologia badań nad edukacja. Warszawa: Wydawnictwa Akademickie i Profesjonalne.

Ryan S. , Mercer, S. 2012. „Implicit Theories: Language Learning M indsets”. (w) S. Mercer, S. Ryan i M. Williams (wyd.) Psychology for Language Learning, Palgrave Macmillan: 74-89.

Smuk, M. 2016. Od cech osobowości do kompetencji savoir-être - rozwijanie samoświadomości w nauce języków obcych. Lublin - Warszawa: Werset.

van der Slik, F. W. P., van Hout, R. W. N. M., Schepens, J. J. 2015. „The Gender Gap in Second Language Acquisition: Gender Differences in the Acquisition of Dutch among Immigrants from 88 Countries with 49 M other Tongues". PLOSONE 10(11): e0142056. https://doi.org/10.1371/journal.pone.0142056, DW 08.08.2017.

Wilczyńska, W., Michońska-Stadnik, A. 2010. Metodologia badań w glottodydaktyce. Wprowadzenie. Kraków: Avalon. 